\title{
PENGARUH MODEL PEMBELAJARAN INQUIRY TRAINING DENGAN MENGGUNAKAN MEDIA ANIMASI TERHADAP KETERAMPILAN PROSES SISWA PADA MATERI ALAT-ALAT OPTIK DI KELAS X SEMESTER GENAP SMA NEGERI 5 BINJAI T. P. 2014/2015
}

\author{
Tariza Fairuz dan Mara Bangun Harahap \\ Jurusan Fisika FMIPA Universitas Negeri Medan \\ Jalan Willem Iskandar Pasar V Medan, Sumatera Utara \\ tarizafairuz@gmail.com
}

Penelitian ini bertujuan untuk mengetahui pengaruh model pembelajaran inquiry training dengan menggunakan media animasi terhadap keterampilan proses siswa pada materi alat optik di kelas X semester genap SMA Negeri 5 Binjai T.P 2014/2015. Jenis penelitian ini adalah quasi eksperimen dengan desain two group pretest and posttest. Populasi dalam penelitian adalah seluruh siswa kelas X MIA SMA Negeri 5 Binjai yang terdiri dari 4 kelas. Pemilihan sampel dilakukan secara cluster random sampling dan terpilih kelas X MIA-1 sebagai kelas eksperimen dan kelas X MIA-3 sebagai kelas kontrol yang masing-masing berjumlah 35 orang. Instrumen yang digunakan untuk mengetahui keterampilan proses siswa adalah tes keterampilan proses dalam bentuk esai sebanyak 10 soal. Berdasarkan analisa data, nilai rata-rata pretes kelas eksperimen 51,37 dan kelas kontrol 51,11. Kedua kelas berdistribusi normal, homogen, dan memiliki kemampuan awal yang sama. Kemudian diberikan perlakuan, kelas eksperimen dengan model pembelajaran inquiry training dengan media animasi dan kelas kontrol dengan model pembelajaran konvensional. Nilai rata-rata postes kelas eksperimen 74,14 dan kelas kontrol 68,80. Hasil uji $\mathrm{t}$ diperoleh $\mathrm{t}_{\text {hitung }}=2,053$ dan $\mathrm{t}_{\text {tabel }}=$ 1,997 sehingga $t_{\text {hitung }}>t_{\text {tabel }}$ maka $H_{o}$ ditolak, yang berarti ada perbedaan akibat pengaruh model pembelajaran inquiry training dengan menggunakan media animasi terhadap keterampilan proses siswa pada materi alat-alat optik di kelas $\mathrm{X}$ semester genap SMA Negeri 5 Binjai T.P 2014/2015.

Kata kunci: inquiry training, media animasi, keterampilan proses

\section{ABSTRACT}

This study aimed to determine the effect of inquiry training learning model used animation media on process skills of students in the subject matter optical instruments in the second half at class X SMA Negeri 5 Binjai A.Y 2014/2015. This study was a quasi-experimental with two group pretest and posttest design. The population in the study were all students of class X MIA SMA Negeri 5 Binjai consisted of 4 classes. Sample selection is done by cluster random sampling and class X MIA-1 as the experimental class with 35 students and class X MIA-3 as a control class with 35 students. The instrument that used to determine the process skills of the students is process skills test in essay form as many as 10 questions. Based on data analysis, the average value of pretest on experimental class is 51.37 and control class is 51.11. Both classes are normally distributed, homogenous, and have the same ability. Then they are given a treatment, experimental class with inquiry training learning model used animation media and control class with conventional learning models. The average value of posttest on experimental class 74.14 and control class 68.80. T-test results 
obtained $t_{\text {calculation }}=2.053$ and $t_{\text {table }}=1.997$ so $t_{\text {calculation }}>t_{\text {table }}$, then $H_{o}$ is rejected, which means that there are differences due to the effect of inquiry training learning model used animation media on process skills of students in the subject matter optical instruments in the second half at class X SMA Negeri 5 Binjai A.Y 2014/2015.

Keywords : inquiry training, animation media, proccess skill

\section{INTRODUCTION}

Fisika merupakan ilmu yang mempelajari tentang semua peristiwa dan gejala fisis yang terjadi di alam. Pengetahuan fisika diperoleh dan dikembangkan dengan berlandaskan pada serangkaian penelitian yang dilakukan fisikawan dalam mencari jawaban pertanyaan apa, mengapa, bagaimana dari gejala-gejala alam serta penerapannya dalam kehidupan sehari-hari. Fisika sebagai mata pelajaran menuntut siswa untuk lebih memahami konsep fisika dan mampu mengaplikasikannya ke dalam kehidupan sehari-hari. Namun fakta yang ada bahwa fisika merupakan mata pelajaran yang memiliki hasil terendah di antara mata pelajaran eksakta lainnya.

Faktor yang menyebabkan rendahnya hasil fisika antara lain; kualitas guru, minat belajar siswa, sarana pembelajaran atau media pembelajaran, status sosial, dan lingkungan. Dari sisi guru misalnya, guru biasanya hanya menggunakan model konvensional tanpa media pembelajaran, sehingga siswa bosan. Siswa tidak terlalu memahami konsep fisika sehingga mereka hanya terfokus pada rumus-rumus yang ditulis di papan dan tidak mampu mengaplikasikannya ke dalam kehidupan sehari-hari sehingga siswa menjadi pasif dan menganggap fisika adalah pelajaran yang paling sulit dibanding pelajaran eksakta lainnya.

Sesuai dengan pengalaman peneliti saat melakukan Program Pengalaman Lapangan Terpadu (PPLT), banyak siswa yang menyatakan bahwa pelajaran fisika itu merupakan pelajaran yang kurang menarik. Mereka juga cenderung menganggap pelajaran fisika salah satu pelajaran yang membosankan, karena selalu identik dengan rumus yang banyak dan susah untuk diingat. Guru lebih sering menggunakan pola mengajar dengan menyajikan materi dan penyelesaian soal-soal dengan rumus. Siswa hanya dapat menghitung tetapi tidak dapat mengerti konsep fisika sebenarnya. Dalam proses pembelajaran, khususnya pembelajaran fisika guru merupakan figur yang harus pandai memilih metode, media maupun model pembelajaran yang akan digunakan untuk menjelaskan materi pelajaran agar tercapai sesuai dengan tujuan.

Berdasarkan hasil wawancara dengan salah satu guru fisika di SMA Negeri 5 Binjai, menyatakan bahwa hanya 50\% dari 35 orang siswa yang mampu mencapai nilai Kriteria Ketuntasan Minimal atau KKM, yaitu 70. Model pembelajaran yang digunakan adalah model konvensional yaitu pola mengajar yang cenderung menggunakan metode ceramah dan penugasan. Selain itu, guru belum pernah menggunakan model inquiry training dan media animasi dalam pembelajarannya di kelas sedangkan sarana media pembelajaran tersedia cukup baik di sekolah tersebut, seperti adanya proyektor dan laboratorium fisika. Hal ini mengakibatkan kemampuan siswa seperti melakukan pengamatan, merumuskan hipotesis, menggunakan alat, mengumpulkan data, mengidentifikasi variabel, membuat kesimpulan dan kegiatan yang lain dapat mengembangkan keterampilan proses ilmiah yang ada pada diri siswa tidak tampak.

Permasalahan di atas sebenarnya dapat diatasi jika guru dapat melihat permasalahan-permasalahan di kelas dan mencari model pembelajaran yang tepat untuk menyelesaikan masalah tersebut, agar materi pembelajaran dapat diserap dan 
dipahami siswa dengan baik dan siswa tidak kesulitan dalam menerima pelajaran. Salah satu model pembelajaran yang dapat meningkatkan keterampilan proses siswa adalah model pembelajaran inquiry training.

Model pembelajaran inquiry training ini diarahkan untuk mengajarkan siswa dalam proses mengkaji dan menjelaskan suatu fenomena khusus. Tujuannya adalah membantu siswa mengembangkan keterampilan intelektual yang diperlukan untuk mengajukan pertanyaan dan menemukan jawabannya berdasarkan rasa ingin tahunya.

Melalui model pembelajaran inquiry training ini siswa diharapkan aktif mengajukan pertanyaan mengapa sesuatu terjadi kemudian mencari dan mengumpulkan serta memproses data secara logis untuk selanjutnya mengembangkan strategi intelektual yang dapat digunakan untuk menemukan jawaban atas pertanyaan mengapa sesuatu terjadi.

Siswa yang menghadapi situasi tersebut akan termotivasi menemukan jawaban masalah-masalah yang masih menjadi teka-teki. Hal ini sesuai dengan teori Suchman dalam Joyce, dkk., (2011) yang menerapkan model pembelajaran dari fakta menuju teori atau from facts to teories. Selain itu, guru juga dapat menggunakan kesempatan ini untuk mengajarkan prosedur pengkajian sesuai dengan langkah-langkah pembelajaran inquiry training.

Penelitian sebelumnya yang dilakukan oleh Pandey, dkk., (2011), diperoleh bahwa berdasarkan tes prestasi ilmu fisika atau Achievement Test in Physical Science (ATPS), penggunaan model pembelajaran inquiry training lebih efektif dibandingkan dengan penggunaan model konvensional di kelas IX. Penelitian juga dilakukan oleh Sari (2014), diperoleh hasil penelitian dengan pemahaman konsep fisika siswa sebelum dilaksanakan model pembelajaran inquiry training dan setelah dilaksanakan model pembelajaran inquiry training mengalami peningkatan yang cukup signifikan.

Penelitian yang sama dengan menggunakan model pembelajaran inquiry training dilakukan oleh Hasibuan (2014). Berdasarkan hasil penelitian yang dilakukan oleh Setiawan di kelas VII Semester ganjil SMP Daya Cipta Medan, diperoleh hasil belajar IPA siswa yang dilihat dari hasil postes siswa di kelas eksperimen 73,4, sedangkan pada kelas kontrol nilai postes 59,2. Hasibuan (2014) melakukan penelitian di kelas X Semester genap SMA Negeri 1 Percut Sei Tuan. Hasil penelitian yang diperoleh menunjukkan nilai rata-rata pretes 38,86 dan setelah diberi perlakuan yaitu dengan model pembelajaran inqury training diperoleh nilai rata-rata postes 76,29. Dari hasil kedua penelitian tersebut terdapat peningkatan terhadap hasil belajar siswa dengan menggunakan model pembelajaran inquiry training.

Perbedaan penelitian terdahulu dengan penelitian yang akan diteliti adalah peneliti menggunakan media animasi. Peneliti bermaksud untuk melihat apakah penggunaan media animasi dengan model inquiry training dalam pembelajaran fisika dapat meningkatkan keterampilan proses siswa.

Media animasi adalah salah satu media pembelajaran nonfisik menggunakan perangkat lunak komputer. Perangkat lunak yang digunakan dalam pembuatan animasi ini adalah macromedia flash yang diproduksi oleh Adobe Flash. Adobe Flash digunakan untuk membuat gambar vektor maupun animasi gambar. Pembelajaran yang menggunakan media animasi efektif membantu siswa untuk berfikir mengenai konsep-konsep fisika yang bersifat abstrak dan dapat meminimalisir kesalahpahaman yang mungkin terjadi.

Berdasarkan uraian di atas, peneliti melakukan penelitian dengan tujuan untuk melihat pengaruh model pembelajaran inquiry training dengan menggunakan media animasi terhadap keterampilan proses siswa pada materi Alat-alat Optik di 
Kelas X Semester Genap SMA Negeri 5 Binjai T.P 2014/2015."

\section{METODE PENELITIAN}

Penelitian ini dilaksanakan di SMA Negeri 5 Binjai pada bulan Mei tahun 2015 di semester genap T.P 2014/2015. Populasi dalam penelitian ini adalah siswa kelas X SMA Negeri 5 Binjai yang terdiri dari 4 kelas. Sampel dalam penelitian ini terdiri dari dua kelas yaitu kelas kontrol dan kelas eksperimen yang diambil dengan teknik cluster random sampling. Kelas $\mathrm{X}$ MIA-1 sebagai kelas eksperimen dan kelas $\mathrm{X}$ MIA-3 sebagai kelas kontrol dengan masing-masing jumlah siswa 35 orang.

Jenis penelitian ini adalah quasi experiment dengan melibatkan dua kelas yang diberi perlakuan yang berbeda untuk mengetahui keterampilan proses siswa. Desain penelitian ini adalah two group pretest-posttest design seperti ditunjukkan pada Tabel 1.

Tabel 1. Desain Penelitian

\begin{tabular}{lccc}
\hline \multicolumn{1}{c}{ Kelas } & Pretes & Perlakuan & Postes \\
\hline Eksperimen & $\mathrm{T}_{1}$ & $\mathrm{X}$ & $\mathrm{T}_{2}$ \\
Kontrol & $\mathrm{T}_{1}$ & $\mathrm{Y}$ & $\mathrm{T}_{2}$ \\
\hline
\end{tabular}

Keterangan:

$\mathrm{T}_{1}=$ Pretest

$\mathrm{X}=$ Pengajaran dengan menerapkan model pembelajaran inquiry training dengan media animasi

$\mathrm{Y}=$ Pengajaran dengan menerapkan model konvensional

$\mathrm{T}_{2}=$ Posttest

Instrumen yang digunakan adalah tes keterampilan proses siswa yang berjumlah 10 soal dalam bentuk esai. Tes ini diberikan sebanyak 2 kali yaitu pada saat pretes dan postes.

Uji hipotesis yang dilaksanakan dengan membandingkan rata-rata skor hasil belajar yang dicapai baik kelompok eksperimen maupun kelompok kontrol. Data yang diperoleh ditabulasikan kemudian dicari rata-ratanya. Sebelum dilakukan penganalisisan data, terlebih dahulu ditentukan skor masing-masing kelompok sampel lalu dilakukan pengolahan data dengan langkah-langkah sebagai berikut: a) Menghitung nilai ratarata dan simpangan baku, b) Uji normalitas, c) Uji homogenitas dan d) Pengujian hipotesis (Uji t).

Uji normalitas dan uji homogenitas dimaksudkan sebagai prasyarat melakukan uji hipotesis. Uji hipotesis dua pihak menggunakan uji $t$ digunakan untuk mengetahui kesamaan kemampuan awal siswa pada kedua kelompok sampel. Hipotesis yang diuji berbentuk :

$$
\begin{aligned}
& \mathrm{H}_{\mathrm{o}}: \mu_{1}=\mu_{2} \\
& \mathrm{H}_{\mathrm{a}}: \mu_{1} \neq \mu_{2} \\
& \text { Uji hipotesis atu pihak menggunakan }
\end{aligned}
$$
uji $\mathrm{t}$ digunakan untuk mengetahui apakah keterampilan proses siswa dengan menerapkan model pembelajaran inquiry training dengan menggunakan media animasi lebih baik dibandingkan dengan model pembelajaran konvensional pada materi pokok Alat-alat Optik. Hipotesis yang diuji berbentuk:

$$
\begin{aligned}
& \mathrm{H}_{\mathrm{o}}: \mu_{1}=\mu_{2} \\
& \mathrm{H}_{\mathrm{a}}: \mu_{1}>\mu_{2}
\end{aligned}
$$

$\mu_{1}=$ skor rata-rata hasil belajar kelas eksperimen

$\mu_{2}=$ skor rata-rata hasil belajar kelas kontrol

\section{HASIL DAN PEMBAHASAN}

Hasil penelitian ini adalah bahwa nilai rata-rata pretes kelas eksperimen sebesar 51,37 dan nilai rata-rata pretes kelas kontrol sebesar 51,11. Setelah diberikan perlakuan yang berbeda, dimana pada kelas eksperimen diberikan pembelajaran dengan model inquiry training dengan menggunakan media animasi dan pada kelas kontrol diberikan model pembelajaran konvensional, diperoleh bahwa rata-rata postes kelas eksperimen sebesar 74,14 dan rata-rata postes kelas kontrol sebesar 68,80. Berdasarkan hasil ini tampak bahwa nilai postes kelas eksperimen lebih tinggi dibandingkan dengan kelas kontrol. Data nilai pretes dan postes pada kelas 
eksperimen dan kelas kontrol masing-2 masing ditunjukkan pada Tabel 2 dan Tabel 22 \begin{tabular}{lll}
23 & 90 & 2 \\
\hline
\end{tabular} 3.

Tabel 2. Data Nilai Pretes Kelas Eksperimen Jumlah 35

\begin{tabular}{lll}
21 & 83 & 1 \\
\hline 22 & 85 & 1 \\
\hline 23 & 86 & 1 \\
\hline 24 & 87 & 1
\end{tabular}
dan Kelas Kontrol

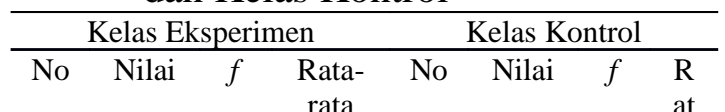

Sebelum dilakukan uji hipotesis menggunakan uji $\mathrm{t}$, data pretes dan postes terlebih dahulu dilakukan uji normalitas dengan menggunakan uji Lilliefors dan uji

\begin{tabular}{ccc}
\hline 1 & 22 & 1 \\
\hline 2 & 27 & 1 \\
\hline 3 & 35 & 3 \\
\hline 4 & 36 & 3 \\
\hline 5 & 38 & 1 \\
\hline 6 & 40 & 2 \\
\hline 7 & 43 & 3 \\
\hline 8 & 45 & 2 \\
\hline 9 & 46 & 1 \\
\hline 10 & 49 & 1 \\
\hline 11 & 50 & 1 \\
\hline 12 & 53 & 2 \\
\hline 13 & 54 & 1 \\
\hline 14 & 59 & 1 \\
\hline 15 & 60 & 2 \\
\hline 16 & 65 & 1 \\
\hline 17 & 66 & 1 \\
\hline 18 & 67 & 1 \\
\hline 19 & 69 & 2 \\
\hline 20 & 72 & 2 \\
\hline 21 & 76 & 1 \\
\hline 22 & 77 & 1 \\
\hline 23 & 82 & 1 \\
\hline & &
\end{tabular}
homogenitas dengan menggunakan uji varians. Berdasarkan uji Lilliefors diperoleh data pretes dan postes berdistribusi normal dan berdasarkan uji varians, diperoleh data homogen. Hasil uji t data pretes dan postes masing-masing ditunjukkan Tabel 4 dan Tabel 5.

Tabel 4. Ringkasan Perhitungan Uji Hipotesis Pretes

\begin{tabular}{ccccc}
\hline Kelas & $\begin{array}{c}\text { Rata- } \\
\text { Rata }\end{array}$ & $t_{\text {hitung }}$ & $t_{\text {tabel }}$ & $\begin{array}{c}\text { Kesim- } \\
\text { pulan }\end{array}$ \\
\hline Eksperimen & 51,37 & & & $\begin{array}{c}\text { Kemam- } \\
\text { puan } \\
\text { Kontrol }\end{array}$ \\
\hline 51,11 & 0,077 & 1,997 & $\begin{array}{c}\text { awal } \\
\text { sama. }\end{array}$ \\
\hline
\end{tabular}

Tabel 5. Ringkasan Perhitungan Uji Hipotesis Postes

\begin{tabular}{ccccc}
\hline Kelas & $\begin{array}{c}\text { Rata- } \\
\text { Rata }\end{array}$ & $\mathrm{t}_{\text {hitung }}$ & $\mathrm{t}_{\text {tabel }}$ & Kesimpulan \\
\hline Eksperimen & 74,14 & 2,053 & 1,997 & $\begin{array}{c}\text { Ada perbedaan } \\
\text { akibat pengaruh } \\
\text { model inquiry } \\
\text { training dengan } \\
\text { menggunakan } \\
\text { Kontrol }\end{array}$ \\
\hline
\end{tabular}

Berdasarkan data penelitian dapat dilihat pada kelas eksprimen yang diajar dengan menggunakan model pembelajaran inquiry training dengan menggunakan media animasi diperoleh hasil nilai rata-rata pretesnya 51,37 sedangkan nilai rata-rata postes adalah 74,14. Di kelas kontrol yang diajar dengan menggunakan pembelajaran konvensional diperoleh hasil nilai rata-rata pretesnya 51,11 dan nilai rata-rata postes adalah 68,80.

Peningkatan nilai rata-rata tes keterampilan proses siswa di kelas eksperimen ini dikarenakan pada saat pembelajaran dengan menggunakan model 
pembelajaran inquiry training menggunakan media animasi, siswa dilibatkan langsung dalam pembelajaran, sehingga siswa menjadi aktif dan kemampuan berpikir siswa dilatih untuk mencari, menyelidiki dan menganalisis pemecahan suatu masalah dan media animasi yang digunakan berisi animasi yang sesuai materi pembelajaran dan siswa dituntut untuk bekerja sama dalam menemukan sendiri informasi yang berkaitan dengan masalah yang diberikan. Dibandingkan dengan pembelajaran konvensional, siswa belajar lebih banyak mendengarkan penjelasan di depan kelas dan melaksanakan tugas jika diberikan latihan soal-soal kepada siswa. Sistem konvensional yang dilakukan dalam pembelajaran yaitu dengan menggunakan metode ceramah, tanya jawab dan pada pertemuan terakhir guru memberikan tugastugas, sehingga siswa merasa bosan, pasif dan mudah cepat lupa.

Keadaan tersebut sejalan dengan hasil penelitian yang dilakukan oleh Vaishnav (2013:1219), diperoleh nilai rata-rata postes kelas eksperimen lebih tinggi dibandingkan nilai rata-rata postes kelas kontrol dan hal ini membuktikan bahwa ada pengaruh model pembelajaran inquiry training terhadap prestasi belajar siswa dengan $t_{\text {hitung }}$ 4,70 dengan taraf signifikan 0,01. Penelitian yang dilakukan oleh Hasibuan (2014), diperoleh hasil penelitian bahwa ada pengaruh yang signifikan menggunakan model pembelajaran inquiry training terhadap hasil belajar siswa. Hal ini dapat dibuktikan dengan perolehan nilai rata-rata postes siswa kelas eksperimen adalah sebesar 76,29 sedangkan untuk siswa kelas kontrol diperoleh nilai rata-rata postes 62,86. Penelitian yang dilakukan oleh Pandey, dkk., (2011:7), diperoleh bahwa berdasarkan tes prestasi ilmu fisika atau Achievement Test in Physical Science (ATPS), penggunaan model pembelajaran inquiry training lebih efektif dibandingkan dengan penggunaan model konvensional di kelas IX.
Menurut Joyce, dkk., (2011: 202), tujuan umum inquiry training adalah membantu siswa mengembangkan disiplin intelektual dan keterampilan yang mampu untuk meningkatkan pertanyaan-pertanyaan dan pencarian jawaban yang terpendam dari rasa keingin-tahuan mereka. Siswa dapat memperoleh dan memproses data secara logis. Siswa dapat mengembangkan strategi-strategi intelektual umum yang dapat digunakan untuk mencari tahu terjadinya fenomena atau peristiwa tertentu. Model pembelajaran inquiry ini juga dapat melayani kebutuhan siswa yang memiliki kemampuan di atas rata-rata. Artinya, siswa yang memiliki kemampuan belajar bagus tidak akan terhambat oleh siswa yang lemah dalam belajar.

Model pembelajaran inquiry training mengajarkan siswa tentang proses dalam meneliti dan menjelaskan fenomena asing, mengajak siswa untuk terlibat secara maksimal untuk mencari dan menyelidiki secara sistematis, kritis, logis, analitis, sehingga mereka dapat merumuskan sendiri penemuannya dengan penuh percaya diri. Model pembelajaran inquiry training menekankan pada pengembangan aspek pengetahuan, sikap, dan keterampilan secara seimbang, sehingga pembelajaran melalui model ini dianggap lebih bermakna (Trianto, 2011:166-167).

\section{KESIMPULAN}

Beradasarkan hasil penelitian ini dapat disimpulkan bahwa keterampilan proses siswa kelas X semester genap SMA Negeri 5 Binjai T.P.2014/2015 dengan menggunakan model pembelajaran inquiry training dengan menggunakan media animasi pada materi alat-alat optik memiliki nilai rata-rata 74,14 sedangkan keterampilan proses siswa kelas X semester genap SMA Negeri 5 Binjai T.P.2014/2015 dengan menggunakan pembelajaran konvensional pada materi alat-alat optik memiliki nilai rata-rata 68,80. Dapat dikatakan bahwa ada pengaruh model pembelajaran inquiry training dengan menggunakan media animasi terhadap 
keterampilan proses siswa pada materi alat optik di kelas $\mathrm{X}$ semester genap di SMA Negeri 5 Binjai T.P 2014/2015.

\section{DAFTAR PUSTAKA}

Hasibuan, T. B. (2014). Pengaruh Model Pembelajaran Inquiry Training Terhadap Hasil Belajar Fisika Siswa pada Materi Suhu dan Kalor di Kelas X Semester II SMA Negeri 1 Percut Sei Tuan T.P. 2013/2014. Skripsi, Universitas Negeri Medan, Medan.

Joyce, B., dkk. (2011). Models of Teaching Model-Model Pengajaran (Edisi Delapan) (A. Fawaid dan A.Mirza, alih bahasa). Yogyakarta: Pustaka Pelajar.

Pandey, A., Nanda G.K., dan Ranjan V. (2011). Effectiveness of Inquiry Training Model over Conventional Teaching Method on Academic
Achievement of Science Students in India. Journal of Innovative Research in Education, 1(1), 7-20.

Sari, R. P. (2014). Penerapan Inquiry Training Model untuk Meningkatkan Motivasi Belajar dan Pemahaman Konsep Fisika Siswa Kelas VIII F SMPN 1 Karangploso, Jurnal Online Universitas Negeri Malang.

Trianto. (2011). Mendesain Model Pembelajaran Inovatif-Progresif, Konsep, Landasan, dan Implementasinya Pada Kurikulum Tingkat Satuan Pendidikan (KTSP). Jakarta: Kencana.

Vaishnav, R. S. (2013). Effectiveness of Inquiry Training Model for Teaching Science, Scholarly Research Journal for Interdisciplinary Studies, 5(1), 1216-1220. 